\title{
Globalization, Labor Market Transformation, and Union Decline in U.S. Metropolitan Areas
}

Todd Vachon

University of Connecticut - Storrs, todd.vachon@uconn.edu

\section{Recommended Citation}

Vachon, Todd, "Globalization, Labor Market Transformation, and Union Decline in U.S. Metropolitan Areas" (2012). Master's Theses. 303.

https://opencommons.uconn.edu/gs_theses/303

This work is brought to you for free and open access by the University of Connecticut Graduate School at OpenCommons@UConn. It has been accepted for inclusion in Master's Theses by an authorized administrator of OpenCommons@UConn. For more information, please contact opencommons@uconn.edu. 
Globalization, Labor Market Transformation, and Union Decline in U.S. Metropolitan Areas

\author{
Todd Vachon \\ M.S., College of Staten Island, 2003 \\ B.A., Marist College, 1998
}

\author{
A Thesis \\ Submitted in Partial Fulfillment of the \\ Requirements of the Degree of \\ Master of Arts \\ At the \\ University of Connecticut
}

2012 
APPROVAL PAGE

Master of Arts Thesis

Globalization, Labor Market Transformation, and Union Decline in U.S. Metropolitan Areas

Presented by

Todd Vachon, M.S.

Major Advisor_Wuhal Wallue

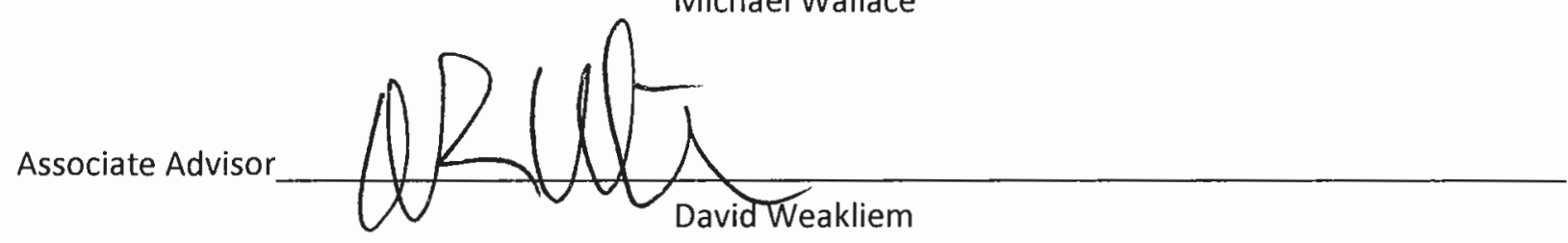

Associate Advisor

University of Connecticut

2012 


\section{Table of Contents}

Title page $\quad$ i

Approval page $\quad$ ii

Table of contents $\quad$ iii

Abstract iv

$\begin{array}{ll}\text { Introduction } & 1\end{array}$

Studying Union Density 3

$\begin{array}{ll}\text { Globalization } & 6\end{array}$

Labor Market Transformation 14

$\begin{array}{ll}\text { Data and Methods } & 20\end{array}$

$\begin{array}{ll}\text { Results } & 24\end{array}$

$\begin{array}{ll}\text { Discussion } & 32\end{array}$

Conclusion $\quad 35$

$\begin{array}{ll}\text { Appendix } & 39\end{array}$

$\begin{array}{ll}\text { References } & 40\end{array}$

$\begin{array}{ll}\text { Figures } & 45\end{array}$

$\begin{array}{ll}\text { Tables } & 46\end{array}$ 


\begin{abstract}
In this study, I analyze the determinants of total, private, and public sector union density among 191 U.S. metropolitan statistical areas in the year 2000. In particular, I examine the effects of five measures of globalization (global capital, foreign direct investment, exports, foreign-born citizens, and foreign-born non-citizens) and four measures of labor market transformation (deindustrialization, corporate restructuring, bureaucratic burden, and casualization) on metropolitan union density while controlling for labor market structure, the business cycle, and the political climate. My analysis demonstrates that: 1) globalization and labor market transformation have moderately negative, but cross-cutting effects on union density; 2) globalization has a greater effect on public sector unions while economic determinants primarily affect private sector unions; and 3) labor market transformation and the political climate strongly affect all three measures of union density. This paper informs theoretical debates on unionization by providing a comprehensive accounting of the impact of globalization and labor market transformation on metropolitan union density.
\end{abstract}




\section{INTRODUCTION}

Labor unions once represented a significant share of the American workforceapproximately $35 \%$ of workers in 1954 (Troy and Sheflin, 1985). This percentage has been steadily declining for more than five decades, and today just under $12 \%$ of the workforce is unionized (Bureau of Labor Statistics, 2010). However, at the local level the decline has not been even, nor has it been universal. On average, total union density - defined as the percent of non-agricultural, wage and salary workers who belong to unions-has declined by 2.2 percentage points in metropolitan areas between 1986 and 2000. Some cities experienced dramatic declines of more than 10 percentage points while others actually saw increases in union density. ${ }^{1}$ This variation in local union density becomes even more pronounced when looking at the private and public sectors separately. On average, private sector metropolitan union density declined by $3 \%$ between 1986 and 2000, while public sector union density increased an average of $2 \%$ during the same period.

Sociologists, economists, and political scientists have been investigating the reasons for variation in union density for decades. These studies have most often been conducted at the national level (Dickens and Leonard, 1985; Freeman, 1988; Jones, 1992; Western, 1997) or the state level (Brady and Wallace, 2000; Ellwood and Fine, 1987; Koeller, 1994; Moore and Newman 1975) and have primarily investigated the extent of unionization among private sector workers. International comparative studies have

\footnotetext{
${ }^{1}$ Five MSAs experienced severe declines in union density of 10 percentage points or more between 1986 and 2000: Modesto, CA, Knoxville, TN, Johnstown, PA, Johnson City, TN, and Bethlehem, PA. Twelve MSAs experienced a growth in total union density during this same period; Des Moines, IA, Erie, PA, Fort Wayne, IN, Huntington, WV, Lansing, MI, Madison, WI, Memphis, TN, Salinas, CA, Stockton, CA, Waterloo, IA, West Palm Beach, FL, and Yuba City, CA. The average growth was $1.8 \%$, with the greatest gain of $5.8 \%$ in Salinas, CA. Just one MSA remained exactly the same; Sacramento, CA at $24.4 \%$.
} 
become common in recent years, analyzing the variation in total (private plus public) union density across industrialized countries (Scruggs and Lange, 2002; Western, 1995). Surprisingly, there has been just one metropolitan-level analysis of union density, conducted by Hirsch (1980), which is now more than thirty years old. Like previous studies, Hirsch's analysis focused largely on political and economic determinants of unionization. While these factors have undoubtedly played an important role in the growth or decline of unions, many things have changed since 1980 and new factors should be considered. For example, the increased intensity and regularity of global economic interaction, the transformation of labor markets to accommodate more flexible work arrangements, and the substantial growth of public sector unions in the face of shrinking private sector unions have likely altered the key determinants of union density. To address these deficiencies in the literature, this cross-sectional analysis makes three contributions to the research on union density: 1) it provides the first comprehensive study of unionization at the metropolitan level in over 30 years, 2) it moves beyond conventional political and economic explanations of union density by considering the effects of globalization and labor market transformation, and 3) it differentiates between the determinants of private and public sector union density.

The following section will consider the benefits of studying unionization at the metropolitan level, review the last metropolitan study of unions, and highlight the need to consider more than the conventional economic determinants of union density. Next, I will review the theorized relationships between globalization, labor market transformation, and union density. I will then introduce the variables and methods before conducting an analysis of the determinants of union density. Finally, I will close with a 
discussion of the results before considering the prospects for future research in the conclusion.

\section{STUDYING UNION DENSITY}

Emphasis on Metropolitan Areas

In his book Segmented Labor, Fractured Politics, William Form (1995)

demonstrates that unions are key actors in the political and economic activity of metropolitan areas. Looking at Cleveland, Columbus, and Cincinnati, Form concluded that societal, economic, and organizational changes have caused a severe decline in labor's political influence. In particular, he draws upon segmentation theory which suggests the heterogeneity of local unions acting in local environments has created internal divisions in the labor movement, weakening its ability to forge a political consensus. While Form is predominantly interested in union political activity, a study of union density must also consider the importance of the forces at work within metropolitan labor markets--after all, business is conducted, employees are hired, and unions are organized at the local level. Thus, I identify four reasons why conducting studies of union density at the metropolitan level is useful.

First, Metropolitan Statistical Areas (MSAs) are cohesive economic entities that share a common work force and transportation infrastructure--unlike state economies that are defined primarily by jurisdictional boundaries. In other words, MSAs are approximations of urban labor markets. Second, MSAs currently account for 114 million jobs, or $85 \%$ of total national employment, and $86 \%$ of the Gross Domestic Product (GDP), making them key drivers of the national economy. In fact, out of the 100 largest economies in the world, 42 are U.S. metropolitan areas, with New York in the top 10, and 
Los Angeles and Chicago in the top 20 (Global Insight, 2006). Third, because the flow of goods and services in and out of metropolitan areas transcends national borders, they represent key nodes of globalization. The amount of variation in global economic exchange across MSAs also captures the geographically uneven nature of globalization. Finally, metropolitan areas vary sufficiently in size, demographic composition, and labor market features, but also in rates of union density, to make them good sites for studying the possible determinants of union density. Thus, in 2000 , union density ranged from $0.6 \%$ in the Lubbock, TX MSA to $33 \%$ in the Duluth-Superior, MI-WI MSA.

\section{Moving Beyond Conventional Frameworks}

The first metropolitan study of union density, conducted by Hirsch in 1980,built upon earlier national- and state-level studies that explained variation in unionization as resulting from two factors - the business cycle and the political climate (Ashenfelter and Pencavel, 1969; Bain and Elsheikh, 1976; Commons et al. 1918). Hirsch utilized an economic framework that conceptualized union membership as an asset that provided services to utility-maximizing workers. Like any asset, Hirsch argued, union membership had a price, and thus the demand for unions fluctuated depending upon that price and the existence of alternatives. The underlying assumption in this kind of model is that union density within MSAs is in equilibrium and that all workers have weighed their options and made the choice to either join or not join a union. Thus, the variation across MSAs is explained exclusively by the difference in costs and options available to workers. This line of reasoning obviously excludes many exogenous factors that can limit or expand workers' ability to actually form unions—factors such as employer resistance (Weiler, 1983) and globalization. In general, however, Hirsch found support 
for his model; in particular, after accounting for simultaneity, the size of the union wage differential was positively associated with union density, and the percentage of whitecollar jobs and the existence of right-to-work laws were negatively associated with metropolitan union density.

Scholars of the labor movement have since acknowledged the problems with exclusively economic explanations of unionization and have begun to incorporate other factors into their theories, such as employer resistance, globalization, and deindustrialization (Clawson and Clawson, 1999). I will focus here on globalizationconceptualized as the intensification of international economic exchange which increases the interconnection between the local and the global—and the corresponding transformation of labor markets to accommodate the economic uncertainty of the global economy. The process of globalization has been temporally and geographically uneven-affecting some cities sooner and more intensely than others. For example, the percentage of employment derived from foreign direct investment (FDI) ranges from $0.7 \%$ in the Billings, MT MSA to $9 \%$ in the Honolulu, HI MSA. Due to this local-level variation, I argue that the effects of globalization on unions can best be evaluated at the metropolitan level, using variables and theoretical constructs that did not exist at the time of Hirsch's study to evaluate the new circumstances that unions now face.

\section{Two Labor Movements}

Previous studies at the state or national level have also limited their focus to either total union density or private sector union density, completely ignoring the distinct trend of public sector union growth (for an exception, see Freeman, 1988). The current percentage of public sector workers unionized is $37.0 \%$, compared to just $6.9 \%$ for 
private sector workers; the corresponding numbers for 1973 were $23.0 \%$ of the public sector and $24.2 \%$ of the private (U.S. Bureau of Labor Statistics). Figure 1 shows how the simultaneous decline of private sector density and expansion of public sector density accounts for the fairly steep decline of total union density in the 1960s and 1970s. Most of the public sector growth can be explained by the passage of state-level collective bargaining laws for public employees in more than a dozen states between 1962 and 1972 (Freeman 1988). Today there are just five states which explicitly prohibit collective bargaining by public employees; the remaining states have various forms of bargaining laws in place which have remained largely unchanged since the $1980 \mathrm{~s}^{2}$ Despite this nearly universal right of public workers to organize, there is no existing study of the variation in public sector organization across metropolitan areas. I will remedy the public sector gap in the literature by simultaneously examining three separate measures of unionization: 1) total union density, 2) private sector union density, and 3) public sector union density. This three-pronged analysis will allow for the first ever comparison of the factors affecting union density in the private and public sectors of employment.

[Figure 1 about here]

The following section will discuss the theoretical links between globalization, labor market transformation and union density.

\section{GLOBALIZATION}

The process of globalization is considered by some to be as old as capitalism itself-dating back to the $16^{\text {th }}$ century (Wallerstein, 2011). Globalization in previous

\footnotetext{
${ }^{2}$ As of 2010, these five states were Virginia, North Carolina, South Carolina, Georgia, and Texas.
} 
centuries was characterized by increased international contact through the regularization of trade among nations; however, many scholars have noted a transformation and intensification of the process since the $1970 \mathrm{~s}$, due in part to advances in communication and transportation technologies (Steger, 2003). This recent surge of global integration has involved a qualitative transformation of the production process through the compression of time and space in a way not previously possible (Brady and Wallace, 2000). While academic accounts of the degree to which globalization has fundamentally transformed the world economy vary greatly, they all agree that cultural, political, and economic phenomena, which were once local, are increasingly connected globally and this has created many challenges for the labor movement (Boswell and Stevis, 1997; Polanyi, 1944). Following Brady, Beckfield, and Zhao (2005), this research will focus on the effects of economic globalization as distinguished from other dimensions of globalization.

Economic globalization, defined as the intensification of international economic exchange, includes investment activities, trade activities, and production activities, which increase the interaction between the local and the global. Investment activity represents the movement of capital across borders either directly in the form of machines and equipment or indirectly in the form of monetary investments. Trade activity represents the movement of commodities in the global market through imports and exports. Production activity encompasses the movement of labor, understood as workers traveling across borders to seek employment or employers seeking cheaper labor sources overseas. Economic globalization exposes metropolitan economies to the international forces of exchange, making local markets into hubs of the world market and often forcing local 
employers and workers to conform to international practices (Sassen, 1999). In this research I follow Wallace, Gauchat, and Fullerton (2010) by looking at four key dimensions of economic globalization: 1) global capital, 2) foreign direct investment, 3) exports, and 4) immigration.

\section{Global Capital}

The term "global capital" refers to the influence of transnational corporations (TNCs), which has increased significantly in recent decades. In 1990 there were approximately 3,000 TNCs; by 2003 there were more than 60,000 TNCs with over 800,000 subsidiaries operating throughout the world (Gabel and Bruner, 2003). Gabel and Bruner note that as of 2003, TNCs employed more than 90 million people and produced $25 \%$ of the world's gross product. The top 1,000 TNCs alone accounted for $80 \%$ of the world's industrial output. Through practices such as offshoring, global capital has led the quest for ever cheaper supplies of labor and natural resources. This can be demonstrated by the amount of consumer goods that are imported into the United States, which in 2001 amounted to $90 \%$ of consumer electronics, $85 \%$ of footwear, $80 \%$ of televisions, $70 \%$ of bicycles, and $60 \%$ of computers (USITC,2002). These labor- and cost-reducing measures have had negative effects on both the quantity and quality of jobs in MSAs that formerly produced these goods. Further, because of the potential for corporations to create high-paying white collar jobs and generate tax revenue, city and state governments compete to attract global capital by offering "business-friendly" environments, characterized by the seemingly contradictory presence of good infrastructure and low corporate tax rates. 
Many of these firms have traditionally been unionized, but the forces of globalization are likely to have reduced their levels of unionization for three reasons. First, TNCs are less likely to be unionized because they offer incentive based pay structures which reduce the likelihood of collective workplace action (Bennett and Kaufman, 2002). Second, the use of global supply chains has decreased demand for local suppliers and eliminated many local production jobs-_jobs that have traditionally been highly unionized (Gereffi and Sturgeon, 2004). Third, the threat of capital flight has applied downward pressure on local wages, thus increasing the exploitation of workers while simultaneously making union organizing more difficult (Bronfenbrenner, 1996). The relationship between global capital and public sector union density is less clear. On the one hand, local governments may try to develop "administrative centers" to attract TNCs and their high paying jobs. This process could involve a large investment in infrastructure, boosting public sector employment. On the other hand, MSAs compete with each other to attract global capital by offering the same (or better) levels of service, infrastructure, and amenities than other cities while still offering a cheaper tax rate. This competition could lead some MSAs to adopt the neoliberal program of reducing taxes on big business - usually paid for by cuts in public spending - in order to attract global capital (Whitfield, 2001). Reductions in government services are likely to eliminate jobs in the highly unionized public sector and increase animosity toward unionization by fiscally squeezed public sector managers.

\section{Foreign Direct Investment}

Accompanying the rise of TNCs has been a sharp increase in the amount of Foreign Direct Investment (FDI) within metropolitan areas. FDI is defined by the 
International Monetary Fund (IMF) as an investment made to acquire lasting interest in an enterprise operating outside of the economy of the investor. In 2010, FDI inflow into the United States accounted for about $\$ 228$ billion or about 1.6\% of GDP, but FDI stock amounted to $\$ 2.5$ trillion or about 17.1\% of GDP (Bureau of Economic Analysis, 2010). FDI demonstrates integration of a local area into the global economy, and increased global integration is believed to have negative consequences for unions (Clawson and Clawson, 1999; Western, 1997). Supporting this claim, Brady and Wallace (2000) observed a negative relationship between FDI and various labor outcomes, including labor dissent, organizational capacity, and economic standing, at the state level. Their pooled time series, state-level analysis for the years 1978-1996 found that manufacturing FDI reduced union membership and that the increase in FDI over the period of their analysis accounted for a $2 \%$ increase in the rate of union decline. Further, various case studies have demonstrated that foreign-owned firms strongly oppose unions and use hegemonic workplace controls and rhetoric about "teams" and "cooperation" with management to avoid unions (Fantasia, Clawson, and Graham, 1988; Graham, 1993; Vallas, 1999).

The negative relationship between FDI and unionization in the private sector, found by Brady and Wallace (2000), could result from three factors: 1) social distancing, 2) enhanced power of capital, and 3) site selection by investors. First, the social distancing between local workers in metropolitan areas and foreign owners who are not located in close geographic proximity means that decisions about pay and working conditions are made by remote managers who generally do not interact with the workforce. Due to this great social distance, foreign owners cannot be held readily 
accountable by workers (Burris, 1993). Brady and Wallace (2000) suggest this situation creates a pro-business, anti-union climate for workers, thus reducing the potential of workers to organize. Second, the ability of foreign-owned firms to relocate, a process known as capital flight, has enhanced the power of capital relative to labor, and likely suppressed the inclination of workers to seek collective redress of grievances. Third, foreign investors may deliberately choose to operate in unorganized areas of the country, such as MSAs in the southern states. This geographic selection process by foreignowned firms contributes to a shift in employment from the more unionized northern cities to less organized metropolitan areas, thus contributing to a negative relationship between FDI and private sector union density.

The effect of FDI on union density in the public sector is hypothesized to be negative for the same reasons that global capital is believed to be. Namely, public sector unions are harmed by the reduction of public spending by local governments trying to make "business-friendly" environments to lure foreign investors. City officials, in search of new ways to create much-needed jobs, see FDI as one possible mean to this end and thus compete with other MSAs to attract FDI. One of the easiest ways for MSAs to compete for FDI is by offering greater services with lower corporate tax rates, a situation which is bad for public sector workers' unions.

\section{Exports}

World trade, like FDI and global capital, is a core dimension of globalization. While the U.S. ranks below most other advanced democracies in trade openness, export activity has increased significantly in recent years. The total value of U.S. exports increased from $8 \%$ of GDP in 1987 to $12 \%$ in 2007 . Arndt and Kierzkowski (2001) attribute a large 
amount of this increase to the fragmentation of production. A single commodity may cross national borders several times in the course of its production before it reaches its final point of assembly or sale. In short, the theory of comparative advantage is now applied to every step of the production process. Labor costs, skill requirements, and proximity to resources and consumers are all factors considered by producers when choosing the best location for each step of the production process. Porter suggests that two logics can determine the location of each phase of production. First, the logic of low cost is based upon bottom-line production costs, and second, the logic of differentiation is based upon the ability of a particular workforce to produce products in a unique way. These two logics correspond to Gordon's (1996) concepts of "low road" versus "high road" economies; specifically, in low road economies such as the U.S., the laborintensive aspects of production are likely to be offshored, while technologically dynamic aspects of production employing small numbers of highly skilled workers, will remain inside the country.

This fragmented form of production can have negative implications for private sector union density for several reasons. First, it creates a global labor market in which workers in the cities of advanced countries are forced to compete with workers in countries with lower costs of living, creating a "race to the bottom (Boswell and Stevis, 1997)." Second, the geographic fragmentation of the production process destroys the potential for worker solidarity by geographically dispersing workers. Third, fragmentation reduces the likelihood of successful collective action because the target can easily relocate (Bronfenbrenner, 1996). Considering these implications, I anticipate the traditional view of export production — which sees it as beneficial to domestic, unionized workers-is no 
longer true in the modern global economy. From this perspective, exports represent an increasingly global and fragmented labor market in which collective action and union organization are stifled by competition between workers.

\section{Immigration}

A fourth dimension of globalization is the influx of immigrants seeking employment in the U.S. While the increase of immigration is indisputable, its effect on union density is still open to debate. Some theorists like Briggs (2001), present the "immigration is bad" argument in which immigrant labor is a threat to established wages and work standards. Others, such as Milkman (2000), present the "immigration is good" argument, in which the influx of immigrants into low-wage jobs with poor working conditions is a catalyst for new union organizing. Both arguments probably overstate the strength of the relationship between the jobs held by new immigrants and the jobs held by unionized native workers. For recent immigrants to pose a real threat to working standards, they would have to hold non-union jobs in unionized sectors of employment, and likewise, to provide an opportunity for new organizing, immigrants would have to hold jobs in organizable sectors of employment. The reality is that the jobs most often held by recent immigrants are very low-paying, undesirable jobs in unorganized and arguably unorganizable areas of the labor market. Further, some researchers have noted a historic anti-immigrant sentiment by many unions, a trend which has recently been reversed in the official policy of union federations in the U.S. and Britain (McGovern, 2007).

I argue that it is useful to distinguish between naturalized and non-citizen immigrants when considering the impact on unionization. Foreign-born workers who have attained citizenship are likely to have stronger English skills, better ties to social 
networks outside of the immigrant community, and more social capital than non-citizen workers who have likely not been in the country as long. Foreign-born workers who are not citizens can be seen as having a greater need for union protection because of the precarious nature of their jobs, but their limited legal rights as non-citizens could deter them from engaging in the often contentious politics of workplace organizing. Further, DeFreitas (1993) found that foreign-born workers, especially Latino immigrants, had more positive views of organized labor than their native counterparts; however they had difficulty securing employment in unionized sectors of the economy. These findings suggest foreign-born citizens who possess the social capital necessary to find unionized employment will do so, while non-citizen immigrants who have recently arrived will be confined to the unorganized sectors of the labor market. For this reason, I expect foreignborn citizens to be positively related and foreign-born non-citizens to be negatively related to union density in both the private and the public sector.

\section{LABOR MARKET TRANSFORMATION}

The structure of the American labor market has changed significantly since the 1970s (Harrison, 1994; Kalleberg, Reskin and Hudson 2000; McCall, 1998). This transformation, which Fullerton and Wallace (2007) call the "flexible turn," has corresponded with increased capitalist competition on a global scale and employers' pursuit of reduced labor costs and increased profits. Associated with economic globalization, labor market transformation involves a set of strategies implemented by employers to respond to the pressures of a globalized economy. In this section, I will consider four effects of labor market transformation: deindustrialization, corporate restructuring, bureaucratic burden, and casualization. 


\section{Deindustrialization}

Since the 1970s, the growing number of inexpensively produced imports has pressured domestic manufacturers to reduce their production costs-often in the form of labor- and wage-saving measures that do not bode well for workers or their unions. Bronfenbrenner's (1996) study of plant closings found that employer threats to close plants in order to avoid unionization shot up to $50 \%$ after the passage of NAFTA, and that $15 \%$ of threats were actually carried out—a three-fold increase from the $1980 \mathrm{~s}$. This wave of outsourcing has led to what Bluestone and Harrison (1982) called the "deindustrialization of America," a process which signaled the shift from a predominantly manufacturing-based economy to a more service-based economy. Beyond the sudden and dramatic actions of plant closures, deindustrialization has also taken place slowly over time through the steady shifting of jobs to new locations (Wallace and Rothschild, 1988). Wallace and Fullerton (2003) found that deindustrialization affected primarily labor-intensive sectors of industry involving low- and semi-skilled jobs that were easier to move to other countries or other regions of the United States. The jobs left behind were difficult to relocate because of dependency on the highly-skilled labor force or other locally-based resources.

Considering the historical strength of organized labor in the manufacturing sector, deindustrialization has surely decreased the relative number of traditionally unionized jobs (Clawson and Clawson, 1999; Freeman, 1988), thus in a time series analysis I would predict a negative relationship between deindustrialization and union density. However, in a cross-sectional analysis, deindustrialization is more likely to represent the degree to which a local area has been a manufacturing center historically. Stated differently, to 
have experienced a large amount of deindustrialization, an MSA must have had a sizeable industrial, and thus union, presence to begin with. MSAs experiencing little or no deindustrialization likely had small manufacturing sectors at the beginning of the period examined. In short, despite decades of deindustrialization, the historically more industrialized MSAs likely remain more unionized than the less industrialized MSAs. Additionally, the highly-skilled manufacturing jobs that remained are more likely to be unionized than the more labor-intensive work that was offshored (Wallace and Fullerton, 2003). This could lead to what appears as a positive relationship between deindustrialization and metropolitan union density, but is in fact a relationship between historically unionized manufacturing cities and their current union density after losing much of their industry. Further, the historic shift of manufacturing from the more unionized northern MSAs to non-union southern MSAs (Grant and Wallace, 1994) may have created a negative relationship between industrial growth and union density. For these reasons, I hypothesize a positive relationship between deindustrialization and metropolitan union density.

\section{Corporate Restructuring}

Corporate restructuring, commonly referred to as downsizing, eliminated an average of 1.6 million jobs per year between 1996 and 2000. This wave of mass layoffs was partly a result of corporate mergers in the early 1990s which created job redundancy and partly due to the outsourcing of work. Whether corporate restructuring primarily affected white-collar or blue-collar workers is contested in the literature. Budros (1997) connects corporate restructuring with deindustrialization into a two-stage process of cost cutting whereby a wave of blue-collar job cuts is followed by a wave of cuts to middle-level 
white-collar positions. While cuts to white-collar jobs may actually increase union density (Hirsch, 1980), blue-collar cuts would reduce union density (Gordon, 1996). McCune, Beatty and Montagno (1988) have suggested that unionized workers are often the target of downsizing measures when employers wish to eliminate inflexible union contracts. Bargained contracts with employees can hinder employers' ability to make rapid workforce changes when facing increased global competition. On the other hand, Allen (1986) and Capelli (2000) believe that union contracts with layoff restrictions or defined benefit pension plans can increase the cost of downsizing for employers, thus reducing the likelihood of costly layoffs of unionized workers. Wallace et al. (2010) found corporate restructuring increased inequality at the lower end of the income distribution in MSAs, suggesting that restructuring affected workers more than managers. Thus, the net effects of corporate restructuring on union density are unclear, but on balance, they would seem to reduce union density.

\section{Bureaucratic Burden}

Gordon (1996) suggests that corporate restructuring left a bloated layer of middleand upper-management positions intact. He calls this phenomenon "bureaucratic burden" and demonstrates its existence by revealing a $7 \%$ growth in management positions as a proportion of all workers within U.S. corporations between 1973 and 1993. Bureaucratic burden could negatively affect private sector union density in several ways. First, a strong and continuous managerial presence can serve as a powerful deterrent to organizing efforts within the shop (Bronfenbrenner and Juravich, 1998). Second, U.S labor laws generally prohibit supervisors from joining unions, which makes the classification of jobs as "managerial" into a backdoor tactic to avoid unionization. 
Finally, the company may be financially incapable of paying better wages to workers because their revenue is overwhelmingly tied up in high managerial salaries. According to Gordon (1996), the U.S., Great Britain, and Canada have higher manager-to-worker ratios than other industrial democracies. These countries, incidentally, also have the most conflictual labor-relations systems and, since the 1980s, relatively low levels of unionization. Since most corporations are situated in metropolitan areas surrounding large cities (Marshall, 1994), the MSA is the ideal level of analysis for comparing the relationship between bureaucratic burden and union density. I expect bureaucratic burden to have a negative relationship with private and public sector union density.

\section{Casualization}

A primary feature of labor market transformation is the shift from traditional to more "flexible" work arrangements (Harrison and Bluestone, 1988). According to Rosenberg (1991), employers have sought three types of flexibility to deal with the uncertainties of the global market: 1) wage flexibility, 2) employment flexibility, and 3) functional flexibility. Being able to adjust the wages, the number of workers, and the work tasks on short notice provides a short-term competitive advantage for employers. These flexible employment systems could be harmful to unions in four ways. First, flexible employment arrangements do not fit as neatly into traditional union contracts as standard work arrangements (Kalleberg et al. 2000). Second, independent contractors are not eligible under the NLRA to form unions. Third, employers in pursuit of flexibility are likely to view collective bargaining as too rigid and thus resist unions more than they would have prior to the flexible turn. Finally, workers employed in flexible jobs are 
simply more difficult to organize for logistical reasons (Bronfenbrenner and Juravich, 1998).

Many employers have increased the flexibility of their workforce by embracing various nonstandard work arrangements, including temporary employment, contract work, on-call work, and new forms of self-employment (Kalleberg, 2000; Smith, 1997). Others have increased their use of part-time and contingent workers. Contingent work (Freedman, 1985) refers to an employment arrangement which lacks an explicit or implicit contract for long-term employment, or an arrangement in which the number of hours worked varies arbitrarily (Polivka and Nardone, 1989). This process of transforming the traditional job into a collection of nonstandard work arrangements has been termed the "casualization of work" by Leslie McCall (1998). McCall (2000) depicts casualization as the sum of part-time or part-year workers, temporary workers, and selfemployed workers in unincorporated businesses. She found on average that $28 \%$ of workers in local labor markets were engaged in casualized employment. Due to the difficulty for unions to organize part-time, temporary, and self-employed workers (Conley and Stewart, 2008), I expect the casualization of work arrangements to have a negative effect on metropolitan union density in the private and public sector.

In Table 1, I summarize the hypothesized effects of globalization and labor market transformation on union density in metropolitan areas. Due to shortcomings in previous research, it is difficult to distinguish separate hypotheses for the private and public sector union density. Thus, hypotheses for the private and public sectors are with only a few exceptions similar to the ones we derive for total union density. The table also 
predicts the effects of labor market structure, the business cycle, and the political climate, which are included as control variables.

[Table 1 about here]

\section{DATA AND METHODS}

\section{Data}

This study will use the Metro_2000 dataset to conduct a cross-sectional analysis of union density at the metropolitan level. There are $276 \mathrm{MSAs}$ in the dataset, but due to missing data on the union variables, the sample for this study is reduced to 191MSAs. The missing data results from 85 MSAs in which the sample sizes were too small to create reliable estimates (Hirsch and MacPherson, 2003). Metropolitan Statistical Areas are defined by the U.S. Office of Management and Budget as geographical areas which “contains a core urban area of 50,000 or more population, and ... includes ... any adjacent counties that have a high degree of social and economic integration (as measured by commuting to work) with the urban core" (U.S. Census Bureau). A complete list of data sources used for this study is available in Appendix A.

\section{Variables}

Dependent Variables

This research will examine three dependent variables from the Union Membership and Coverage Database, available at www. unionstats.com, compiled by Hirsch and MacPherson with data from the Current Population Survey (CPS). Total union density is the proportion of the non-agricultural, wage and salary workforce that belongs to unions, including both public and private sector employment. Private sector density is the proportion of the non-agricultural, wage and salary private sector workforce that belongs 
to unions. Public sector density is the proportion of the government workforce-federal, state, and local-which belongs to unions. ${ }^{3}$ To correct for potentially small samples for some MSAs, three-year moving averages are computed for each dependent variable from 1999,2000 , and 2001 data. I use a logit transformation to create the actual dependent variables used in the analysis:

$$
\operatorname{logit}(p)=\log (p+.01 / 1-p+.01)
$$

where $\mathrm{p}$ is the proportion of the appropriate labor force who are members of unions.

\section{Globalization}

I have identified five measures of globalization which I expect to affect union density. Global capital represents the presence of Fortune 1000 firms within an MSA. Following Wallace et al. (2010), global capital is indexed by summing seven $z$ transformed measures of Fortune 1000 firms in an MSA: number of firms, total sales, total profits, total assets, stockholder equity, market value, and total number of employees. These seven indicators are correlated with each other between .88 and .99 , and the index proves to be highly reliable with a Cronbach's alpha of .84. Second, the amount of foreign direct investment is measured as the percent of employment resulting from FDI. Third, exports/GMP is the value of all exports originating from an MSA as a percentage of its Gross Metropolitan Product (GMP). This value is calculated for 1998 which is the last year for which data were available at the MSA level. Finally, the foreign-born population is divided into two groups: percent foreign-born citizen and percent foreign-born non-citizen.

\footnotetext{
${ }^{3}$ An alternative measure of union density is based on union coverage, rather than membership. Union coverage refers to the percentage of workers covered by collective bargaining agreements, whether or not they are union members.
} 


\section{Labor Market Transformation}

The discussion above identifies four indicators of labor market transformation. Following Wallace and Fullerton (2003), I use data from the Bureau of Labor Statistics (BLS) to measure deindustrialization by dividing the percent of manufacturing employment in 1970 by the percent of manufacturing employment in 2000 and multiplying by 100 . Measures above 100 represent MSAs where deindustrialization has occurred. Corporate restructuring represents the percentage of the labor force involved in a massive layoff between 1996 and $2000 .^{4}$ As defined by the BLS, a mass layoff involves 50 or more workers from one establishment within a five-week period. Bureaucratic burden (Gordon, 1996) is the total salaries of management occupations as a percentage of all salaries within an MSA. The casualization measure (McCall, 2000) sums the percentages of: 1) part-time employment, which offers less than 35 hours per week or less than 40 weeks per year, 2) temporary employment, represented by the industry label "Employment Services," and 3) self-employment, which represents selfemployment in unincorporated businesses.

\section{Control variables}

In this analysis, I introduce control variables for labor market structure, the business cycle, and political climate. The following three variables represent labor market structure. Mean establishment size is the average number of workers per business establishment within the MSA. Percent manufacturing employment and percent government employment represent the percent of non-farm employment in manufacturing and the public sector, respectively. I include three variables to represent the business

\footnotetext{
${ }^{4}$ The corporate restructuring variable is not available at the MSA level, so it is derived from state-level measures, potentially introducing measurement error.
} 
cycle. Unemployment represents the percentage of the labor force that is unemployed.

Economic growth is measured by the percent change in Gross Metropolitan Product

(GMP) between 1991 and 2001. ${ }^{5}$ Cost of living is measured by the price of food, clothing, housing, utilities, and other essential commodities. Cost of living is a proxy for inflation which cannot be directly measured at the metro level. I include four measures to tap the political climate. Republican state government and Democratic state government are dummy variables that identify MSAs within states with Republican or Democratic control of both the state legislature and the governorship. MSAs in states with mixed party control serve as the reference group. Right-to-work is a dichotomous variable indicating whether a metro area falls in a state with a right-to-work law. ${ }^{6} \mathrm{I}$ also include a dummy variable for South to control for the notably non-union political climate of the South. ${ }^{7}$

\section{Method of Analysis}

For this cross -sectional analysis, I use Ordinary Least Squares (OLS) multiple regression to analyze the relationship between the five clusters of independent variables and three dependent variables. This analysis allows for comparison across models for all three dependent variables to reveal similarities and differences in the determinants of

\footnotetext{
${ }^{5} \mathrm{GMP}$ is defined as the annual market value of all goods and services produced in a metropolitan area.

${ }^{6}$ For the 28 MSAs that straddle multiple states, data is used for the state in which the majority of the metropolitan population resides.

${ }^{7}$ MSAs in the South are defined as those located within states in the "South" region as defined by the Bureau of Labor Statistics. These states are: Alabama, Arkansas, Delaware, District of Columbia, Florida, Georgia, Kentucky, Louisiana, Maryland, Mississippi, North Carolina, Oklahoma, South Carolina, Tennessee, Texas, Virginia, and West Virginia. Some factors considered when explaining the low levels of unionization in the South are: the presence of surplus agricultural laborers (Douty, 1946); the lack of largescale industry and skilled labor (Marshall, 1967); the pervasiveness of racism, and a prevailing anti-union ideology (Moore and Newman, 1975); and the existence of RTW laws (Warren and Strauss, 1979).
} 
total, private, and public sector union density. Due to the relatively small number of cases, a significance level of .10 will be used in addition to the conventional $.05, .01$, and .001 levels; significance will be derived from two-tailed tests of significance.

\section{RESULTS}

\section{Descriptive Statistics}

Descriptive statistics for all variables are displayed in Table 2. Starting with the dependent variables, we see that total union density ranges from $0.6 \%$ (Lubbock, TX) to $32.9 \%$ (Duluth-Superior, MN-WI); private sector union density ranges from $0.2 \%$ (Hickory-Morganton-Lenior, NC) to 25.1\% (Duluth-Superior, MN-WI); and public sector union density ranges from 1.3\% (Lubbock, TX) to $71.2 \%$ (Buffalo-Niagara Falls, NY). Among the globalization indicators, the mean level of the global capital measure is 0.2 which reflects the construction of this measure as a sum of seven $z$-scores with a mean of zero for the original 276 MSAs in the Metro_2000 dataset. The minimum, -0.3 represents 168 MSAs in the sample which have no Fortune 1000 firms, and the maximum of 10.0 represents New York City, which has 143 Fortune 1000 firms. ${ }^{8}$ The foreign direct investment variable indicates that on average $4.7 \%$ of employment is derived from foreign investment; ranging from $0.8 \%$ (Billings, MT) to $9 \%$ (Honolulu, $\mathrm{HI}$ ). On average, about $5.4 \%$ of GMP originates from exports, with a low of $0.2 \%$ (Anniston, AL) to a high of $67.3 \%$ (Laredo, TX). The mean percentage of foreign-born

\footnotetext{
${ }^{8}$ The New York City value was reduced from 13.8 to 10 to reduce its outlier status; the next highest MSA was San Francisco-Oakland, which had a score of 6.84, with 47 Fortune 1000, followed by Chicago with a score of 6.42, Dallas with 4.99, and Detroit with 4.08. It should also be noted that four of these top five global capital cities have much higher than average union density-New York (23.3\%), San Francisco (16.5\%) Chicago (18.3\%), Dallas (5\%), Detroit (21.7\%)-which in conjunction with the 168 MSAs with zero Fortune 1000 firms could serve to bias the regression results.
} 
citizens is $2.7 \%$ with a low of $0.4 \%$ (Danville, VA) and a high of $18.5 \%$ (Miami-Fort Lauderdale, FL). The mean percentage of foreign born non-citizens is $4.54 \%$ and ranges from $0.4 \%$ (Wheeling, WV-OH) to $21.7 \%$ (Miami-Fort Lauderdale, FL).

[Table 2 about here]

Turning to the labor market transformation variables, deindustrialization has a mean of 175.8 which indicates that on average the manufacturing sector was about $76 \%$ larger in 1970 than it was in 2000. At 274.3, the Springfield, IL MSA experienced the greatest amount of deindustrialization. Just $10 \mathrm{MSAs}$ in the sample experienced an expansion of their manufacturing sector between 1970 and 2000; the Merced, CA MSA had the greatest growth-about $66.9 \%$. The corporate restructuring measure shows that on average, $3.9 \%$ of employees in metropolitan areas experienced mass layoffs between 1995 and 2000 . The bureaucratic burden measure reveals that on average $16.3 \%$ of all wages and salaries within MSAs went to managerial occupations, ranging from $10.9 \%$ (Utica-Rome, NY) to $28.2 \%$ (Sante Fe, NM). Finally, the mean casualization level is about $16 \%$, with the Sarasota-Bradenton, FL MSA having the most casualized workforce at $24.2 \%$.

\section{Findings for Total Union Density}

Table 3 presents unstandardized and standardized coefficients for five OLS regression models of logit-transformed total union density in U.S. metropolitan areas; robust standard errors are in parentheses. First, looking at just the globalization measures (model 1), we see that three of the indicators achieve statistical significance: global capital and percent foreign-born citizens are positively associated with total union density 
and percent foreign-born non-citizens is negatively associated. Moving next to immigration, the divergent results for the two foreign-born measures are consistent with assumptions about differing levels of social capital and access to social networks for foreign-born citizens versus non-citizens. The foreign-born non-citizen measure has the strongest effect in this model; for a one standard deviation increase in the foreign-born non-citizen population, total union density is reduced by .41 standard deviations, holding all else constant. The low $\mathrm{R}^{2}$ of .06 for this model suggests that globalization alone plays only a small part in determining total union density.

In model 2, I add the four labor market transformation variables which increase the $\mathrm{R}^{2}$ to .34 . Global capital and the immigration variables remain significant and the FDI measure reaches significance in this model. Similar to the findings of Brady and Wallace (2000) it has a negative relationship with unionization. All four measures of labor market transformation are statistically significant. As expected, deindustrialization is positively associated with total union density, which is consistent with the assumption that metropolitan areas with higher deindustrialization display residual unionization from a previous era. The negative effect of bureaucratic burden confirms the hypothesis that greater expenditures on management reduce the likelihood of unionization. This finding demonstrates that MSAs in which management salaries make up a large percent of total earnings are likely to have lower total union density than MSAs spending less.

Casualization is also negatively associated with union density, confirming the hypothesis that highly casualized workforces are more difficult to organize. ${ }^{9}$ Corporate restructuring

\footnotetext{
${ }^{9}$ This variable was tested for endogeneity by way of two-stage least squares regression. The effect of casualization on unionization remained positive even after controlling for the possibility of reciprocal causation.
} 
has a positive relationship with union density, suggesting that mass layoffs between 1995 and 2000 disproportionately targeted unorganized sectors of the labor market.

Turning to the control variables, we see that the three labor market structure indicators show the expected signs in model 3, but none are significant. The minor increase of $\mathrm{R}^{2}$ from .34 to .36 suggests that establishment size, percent manufacturing employment and percent government employment have little net explanatory power for total union density; however, the addition of these variables knocks global capital out of significance and slightly reduces the effects of foreign-born non-citizens, corporate restructuring and casualization. In model 4 , two of the three business cycle variables are significant. Economic growth is negative and cost of living is positive while unemployment has no significant effect. The negative effect of economic growth substantiates the claim that economic expansion is continuing at a faster pace in traditionally non-unionized metropolitan areas, such as those in the south (Grant and Wallace, 1994). The cost of living (a proxy for inflation) is the strongest indicator in this model. For a one standard deviation increase, total union density is expected to increase by .53 standard deviations. The effects for the globalization and labor market transformation variables change slightly with the addition of the business cycle variables. Global capital, while not significant, becomes negative, the positive effect of exports/GMP becomes significant, and the positive effect of foreign-born citizens loses significance. In model 5, I introduce the political controls, and they all perform as expected. Republican state governments, right to work laws, and being in the south all negatively affect the total union density of an MSA. The south variable is the strongest variable in this final model; being in the south reduces the total density of an MSA by .39 
standard deviations. The effects of exports/GMP, corporate restructuring, casualization, and cost of living all lose significance when the political variables are added. The positive effect of foreign-born citizens returns to significance. The findings of these models show mixed support for the argument that globalization and labor market transformation are harmful to unions. In particular, the effects of several variables lose significance in the last model, which demonstrates that political factors still play a very important role in determining total union density at the metropolitan level.

\section{Findings for Private Sector Union Density}

Table 4 presents the results for OLS determinants of logit-transformed private sector union density. In model 1 , just two of the globalization measures are significant: global capital is positive and foreign-born non-citizens is negative at the .10 level. While not significant, the negative relationship between FDI and private sector union density lends support to the argument that foreign-owned corporations are likely to avoid unions in the U.S. The export/GMP variable is positively related to union density, which supports the traditional claim that export production is good for workers and unions, but it does not reach statistical significance. Foreign-born citizens also shows a positive sign, but does not reach significance either. These findings are similar to those in model 1 for total union density. In model 2, we see that all of the labor market transformation variables are significant: deindustrialization and corporate restructuring are positively associated with private sector union density while bureaucratic burden and casualization are negatively associated. The negative effect of FDI also becomes significant in model

2. The labor market transformation variables cause the $\mathrm{R}^{2}$ to increase from .06 in model 1 to .32 in model 2. 
In model 3, average establishment size has a positive relationship with private sector union density at the .10 level. This supports the claim that unions are easier to organize in establishments that employ large numbers of workers. While not significant, manufacturing employment shows a positive sign and government employment shows a negative sign as expected. With the exception of foreign-born citizens reaching significance, the effects of the globalization and labor market transformation variables remain largely unchanged. In model 4 , I show that all three business cycle measures are significant. Unemployment shows a positive relationship with private sector union density, economic growth shows a negative association $(p<.10)$ and cost of living shows a positive association. The unexpected positive effect of unemployment suggests that unions still provide some job security for workers in times of economic decline. Further, periods of high unemployment traditionally reduced union organizing; however, after decades of decline, the surviving unions appear to be less willing to stop organizing during economic downturns. The negative effect of economic growth again supports the hypothesis that new economic growth in the South hurts unions. As in the total density analysis, cost of living has the strongest effect on density in this model; for a one standard deviation increase, private sector union density is expected to increase by .53 standard deviations. Looking back at the globalization variables, foreign-born noncitizens and global capital drop from significance, and the exports/GMP measure becomes significant at the .10 level—a result that is similar to the findings in model 4 for total density.

In the final model, I add the political variables, and they perform similarly for private sector union density as for total union density. Republican state governments and 
right to work laws have strong negative associations with private sector union density, and southern MSAs have lower union density than MSAs in other regions. The inclusion of the political variables increases the $\mathrm{R}^{2}$ from .49 in model 4 to .69 in model 5 , while simultaneously knocking 3 globalization and labor market transformation variables out of significance- exports/GMP, corporate restructuring, and casualization. FDI, deindustrialization, and bureaucratic burden remain significant. The overall findings of model 5 imply that globalization and labor market transformation have mixed effects on private sector union density, traditional economic explanations still hold some weight, and that political climate is critically important when explaining union density in the private sector.

\section{Findings for Public Sector Union Density}

In Table 5, I examine the determinants of logit-transformed public sector union density. Turning first to the globalization variables in Model 1, the results are consistent with those for the total and private sector models: global capital and foreign-born citizens have positive relationships with public sector union density, while foreign-born noncitizens shows a strong negative relationship with public sector union density. Interestingly, the strongest effect in the model is the positive effect of foreign-born citizens; for a one standard deviation increase, public sector union density is expected to increase by .55 standard deviations. This could be attributed to the more egalitarian hiring practices in the public sector, or to the strong pro-union sentiment found among immigrant citizens (DeFreitas, 1993). In model 2, FDI becomes significant and all four labor market transformation variables are significant, again with signs and magnitudes consistent with the total and private sector models. The addition of these variables 
improves the $\mathrm{R}^{2}$ from .10 to .40 . In model 3, manufacturing employment is positive and significant at the .10 level, a finding that is difficult to explain since it did not appear in the private sector, where we would expect to see it. Establishment size and government employment do not reach statistical significance, and casualization loses significance. However, with an $\mathrm{R}^{2}$ increase from .40 in model 2 to .44 in model 3, it is clear that the labor market structure variables alone do not explain much variation in public sector union density.

In model 4, I add the business cycle variables. Consistent with the findings for total and private sector unionization, cost of living is the strongest variable in the model. For a one standard deviation increase, public sector union density is expected to increase by .45 standard deviations. Global capital loses its significance while FDI, bureaucratic burden and casualization become stronger and more significant in this model. Thus, when controlling for the effects of the business cycle, the costs of globalization begin to outweigh the potential benefits for public sector unions. The final model includes all five clusters of variables. FDI drops from significance when the political controls are added; however, foreign-born citizens and non-citizens remain highly significant. Three of four labor market transformation variables remain significant in this model; deindustrialization and corporate restructuring have positive effects, while bureaucratic burden has a negative effect. Of the three control clusters, only the political variables have significance; right to work laws and being in the south have negative effects on public sector union density. The full model thus demonstrates strong effects of globalization and labor transformation on public sector union density. The traditional economic and labor market variables do not explain much of the variation in public sector 
union density at the metropolitan level; however, like the total and private sector models, the political factors explain a lot of the variation.

\section{DISCUSSION}

Taken as a whole, three basic themes emerge from this cross-sectional analysis.

First, globalization and labor market transformation have moderately negative, but crosscutting effects on union density. In both the private and the public sector, four globalization variables and four labor market transformation variables affect union density. Contrary to the hypothesized effect, the presence of global capital is positively related to both private and public sector union density. This relationship is likely an artifact of the measure, namely that Fortune 1000 firms are concentrated in a handful of large cities, but it nonetheless demonstrates the coexistence of large transnational corporations and strong labor movements within the same metropolitan area. In addition to the labor employed directly by these global firms, there could be intervening variables such as increased demand for construction, communication, transportation and other highly unionized services in cities where global capital is headquartered. ${ }^{10}$ Further, these global cities may require substantial public infrastructure, a demand that supports the growth of public sector unions.

The hypothesized negative effect of FDI was found in the private and public sector models. This result reinforces Brady and Wallace's (2000) finding that FDI diminishes organizing capacity. We can now add reduced private and public sector union density to the list of negative labor outcomes associated with FDI. This observation also

\footnotetext{
${ }^{10} \mathrm{~A}$ model not included in this article revealed a significant positive interaction between global capital and change in construction employment between 1990 and 2000, lending some support to the argument that global capital indirectly helps unions in other industries. For a copy of this model contact the author.
} 
supports the findings from a handful of case studies which found foreign-owned firms to be intensely anti-union (Fantasia, Clawson, and Graham, 1988; Graham, 1993; Vallas, 1999). The hypothesized divergence between foreign-born citizens and non-citizens is also supported in this analysis. Metropolitan areas with large foreign-born populations that have been in the country long enough to achieve citizenship have sizeable labor movements, while destinations of new immigrants tend to be less unionized. These findings support DeFreitas's (1993) conclusion that foreign-born workers are more supportive of organized labor than their native counterparts; however, they have more difficulty securing work in the unionized sectors of employment. Once obtaining citizenship these workers are likely to have acquired the necessary social capital to capture the unionized jobs that they desire. Thus, upon arrival, immigrants have a negative association with union density, but once they become established and acquire citizenship, they bolster union density.

Among the labor market transformation variables, deindustrialization has a positive relationship with union density, supporting the hypothesis that former manufacturing centers retain relatively strong labor movements, even after decades of declining manufacturing employment. The relationship is the same for the private and public sectors, signifying that pro-union sentiment in these MSAs reaches beyond the manufacturing sector. Corporate restructuring also shows a positive relationship with union density in both the private and public sectors. This finding contradicts McCune et al.'s (1988) conclusion that unionized workers are the primary target of downsizing corporations, and supports Capelli's (2000) argument that unions may protect workers from corporate restructuring. If union contracts contain restrictions on layoffs that raise 
the costs of downsizing, they can reduce the incentive for private and public employers to cut unionized jobs (Allen, 1986). For example, severance pay provisions and defined benefit pension plans can raise the costs of downsizing by extending employers' financial obligations to employees beyond the term of their employment (Capelli, 2000; Lazear, 1989). I also find support for my hypothesis that bureaucratic burden (Gordon, 1996) and casualization (McCall, 1998) have harmed unions. Both variables have moderate but significant negative effects on union density, suggesting that strong managerial presence and flexible work arrangements are detrimental to union density.

The second theme emerging from this analysis is that globalization and labor market transformation have a greater effect on public sector unions while the business cycle and labor market structure primarily affect private sector unions in the year 2000 . Five of the globalization and labor market transformation variables are significant in the full model for public sector density (foreign-born citizens, foreign-born non-citizens, deindustrialization, corporate restructuring, and bureaucratic burden), while only three are significant in the full model for private sector density (FDI, deindustrialization, and bureaucratic burden). On the other hand, two economic control variables-average establishment size and economic growth-are significant determinants of private sector unionization, but not public sector unionization. This is likely due to the political nature of public sector unions and the economic nature of private sector unions. Public sector unions derive their power from political pressure, often in the form public opinion, while private sector unions derive their strength from power relations within the labor market. In recent years, globalization has become more tightly linked to the ideology of neoliberalism which opposes unions and the public sector in general. This divergence 
between the determinants of private and public sector density reinforces the need to examine them separately in future studies.

Finally, the third theme to emerge in this study is that the political climate strongly affects total union density as well as union density in both the private and public sectors. Republican state governments, right to work laws, and being in the south are all significant determinants of union density across all three measures used in this analysis. Taken together, these findings suggest that globalization and labor market transformation have a balance of positive and negative effects on union density and should thus cancel each other out. However, if we reconsider the nature of the positive relationship between deindustrialization and union density and between corporate restructuring and union density, the scale tips more toward the growing consensus among sociologists that globalization has moderate negative effects on unions (Brady and Wallace, 2000; Western, 1997).

\section{CONCLUSION}

The percentage of American workers who belong to unions has been declining steadily for decades; however, at the local level the decline has not been even, nor has it been universal. Some metropolitan areas experienced dramatic declines in total union density, others experienced modest growth, but by far most MSAs have experienced a minimal, but steady decline in the past two decades. This local-level variation becomes more pronounced when examining private and public sector union density separately. While unionization has been steadily declining in the private sector since the mid-1950s, in the public sector it increased rapidly in the 1960s and 1970s and leveled off thereafter. These changes in total, private, and public sector union density have occurred alongside 
an unprecedented, and also geographically uneven, process of globalization. Sociological studies of unionization within the United States, which were commonplace during the years of high union density, have all but disappeared from the literature since the 1990s. The present study has reopened the question, "What explains local differences in unionization?" and has provided plausible answers to that question.

With the exception of Hirsch (1980), previous studies of union density in the U.S. have failed to consider the metropolitan level. In addition, these studies have considered economic and political determinants of union growth or decline; however, very few have directly examined the effects of economic globalization and labor market transformation. Further, despite the divergent trends of unionization rates between the private and public sectors, only Freeman (1988) has examined the determinants of density in these two sectors separately. I have addressed these shortcomings in the literature in three ways. First, I focused on the metropolitan level of analysis which has been neglected by scholars of union density for more than 30 years. Second, I employed Wallace et al.'s (2010) globalization and labor market transformation framework to examine the effects of these processes on union density across metropolitan areas in the year 2000. Finally, I analyzed the determinants of total, private, and public sector union density separately to reveal the similarities and differences across these different sectors of employment.

Overall, the results of this research offer some support for the claim that economic globalization is bad for unions, particularly the effects of FDI and new immigrants. However, despite the overall trend of declining density, unions have helped workers to weather the storm of mass layoffs, they have managed to organize workers in other areas of employment when manufacturing employment disappeared, and they have benefitted 
from the pro-union sentiments of foreign-born citizens. Many of the findings in this study, such as the positive effect of global capital, demonstrate the importance of examining the variation of union density at the metropolitan level.

Future research on union density should proceed along several avenues. First, future studies should examine unionization in the private and public sectors separately as total union density alone is likely to be misleading. Second, this study has established global capital as a positive determinant of metropolitan union density. To fully understand this relationship, future research could explore the mechanisms at work that are producing this outcome. Such studies might investigate the role of intervening factors such as employment in transportation, utilities and communications as well as the history of unionization in these areas over time. Third, our understanding of metropolitan union density would benefit from longitudinal studies that capture the effects of changes in these variables over time. Cross-sectional studies provide valuable information when exploring the causes of variation across space; however, the dimension of time could be particularly relevant considering the divergent trends of unionization in the different sectors of employment. Finally, the present study does not encompass all the possible factors that might explain variation in union density. Future studies could examine a wider range of determinants or focus on different theoretical perspectives, such as the rogue employer hypothesis which attributes union decline largely to the hostile actions of employers.

In conclusion, this study builds upon a rich history of studies to re-open the black box of union density. In a specific way, it adds to a growing body of research on the effects of globalization on working people and, like much of that research, highlights the 
mixed effects of globalization. At a more general level, this study reveals that political and economic factors still play an important role in explaining variation in union density across areas. Labor scholars and activists interested in union revitalization should consider the positive effects of global capital, foreign-born citizens, and cost of living on union density, as their influences may point to how future organizing campaigns might reverse the ongoing trend of union decline. 


\section{REFERENCES}

Allen, Stephen. 1986. "Union Work Rules and Efficiency in the Building Trades." Journal of Labor Economics 4:212-42.

Arndt, Sven W., and Henryk Kierzkowski. 2001. Fragmentation: New Production Patterns in the World Economy. New York, NY: Oxford University Press.

Ashenfelter, Orley, and John H. Pencavel. 1969. "American Trade Union Growth: 19001960." Quarterly Journal of Economics 73:162-69.

Bain, George S., and Farouk Elsheikh. 1976. Union Growth and the Business Cycle: An Econometric Analysis. Oxford, UK: Blackwell.

Bennett, James T., and Bruce E. Kaufman. 2002. The Future of Private Sector Unionism in the United States. Armonk, NY: M.E. Sharpe Inc.

Bluestone, Barry, and Bennett Harrison. 1982. The Deindustrialization of America: Plant Closings, Community Abandonment, and the Dismantling of Basic Industry. New York: Basic Books.

Boswell, Terry, and Dimitris Stevis. 1997. "Globalization and International Labor Organizing." Work and Occupations 24:288-308.

Brady, David, Jason Beckfield, and Wei Zhao. 2005. "The Consequences of Economic Globalization for Affluent Democracies." Annual Review of Sociology 33:31334.

Brady, David, and Michael Wallace. 2000. "Spatialization, Foreign Direct Investment, and Labor Outcomes in the American States, 1978-1996." Social Forces 79:67-105.

Briggs, Vernon M. 2001. Immigration and American Unionism. Ithaca, NY: Cornell University Press.

Bronfenbrenner, Kate. 1996. "Final Report: The Effects of Plant Closing or Threat of Plant Closing on the Right of Workers to Organize." International Publications Paper

1. Retrieved May 1, 2011 (http://digitalcommons.ilr.cornell.edu/intl/1).

Bronfenbrenner, Kate, and Tom Juravich. 1998. "It Takes More than House Calls to Win: Organizing to Win with a Comprehensive Union-Building Strategy." Pp. 19-36 in Organizing to Win: New Research on Union Strategies, edited by

Bronfenbrenner, K., Friedman, S., Hurd, R. W., Oswald, R. A., and Seeber, R. L.. Ithaca, NY: ILR/Cornell University Press.

Budros, Art. 1997. "The New Capitalism and Organizational Rationality: The Adoption of Downsizing Programs, 1979-1994." Social Forces 79:67-105. 
Gabel, Medard, and Henry Bruner. 2003. Global Inc.: An Atlas of the Multinational Corporation. New York, NY: The New Press.

Capelli, Peter. 2000. "Examining the Incidence of Downsizing and its Effect on Establishment Performance." Working Paper No. 7742, National Bureau of Economic Research, Cambridge, MA.

Clawson, Dan, and Mary Ann Clawson. 1999. "What Has Happened to the Union Movement?: Union Decline and Renewal." Annual Review of Sociology 25:95-119.

Commons, John R., David J. Saposs, Helen L. Sumner, E.B. Mittelman, H.E. Hoagland, John B. Andrews, and Selig Perlman. 1918. History of Labor in the United States. New York, NY: Kelley.

Conley, Hazel, and Paul Stewart. 2008. "Representing Fixed-Term Workers: The Anatomy of a Trade Union Campaign." Employee Relations 30:515-33.

Defreitas, Gregory. 1993. "Unionization Among Racial and Ethnic Minorities." Industrial and Labor Relations Review 46:284-301.

Dickens, William T., and Jonathan S. Leonard. 1985. "Accounting for the Decline in Union Membership, 1950-1980." Industrial Labor Relations Review 38:323-34.

Douty, H.M. 1946. "Development of Trade Unionism in the South." Monthly Labor Review 63:555-82.

Ellwood, David T., and Glen Fine. 1987. "The Impact of Right-to-Work Laws on Union Organizing." Journal of Political Economy 95:250-73.

Fantasia, Rick, Dan Clawson, and Gregory Graham. 1988. "A Critical Review of Worker Participation in American Industry." Work and Occupations 15:468-88.

Form, William. 1995. Segmented Labor, Fractured Politics: Labor Politics in American Life. New York, NY: Plenum Press.

Freedman, Audrey. 1985. Conference Board Report No. 865: The New Look in Wage Policy and Employee Relations. New York, NY: The Conference Board.

Freeman, Richard B. 1988. "Contraction and Expansion: The Divergence of Private Sector and Public Sector Unionism in the United States." Journal of Economic Perspectives 2:63- 88 .

Fullerton, Andrew S., and Michael Wallace. 2007. "Traversing the Flexible Turn: U.S. Workers' Perceptions of Job Security, 1977-2002." Social Science Research 36:201-21.

Gabel, Medard, and Henry Bruner. 2003. Global Inc.: An Atlas of the Multinational Corporation. New York, NY: The New Press. 
Gereffi, Gary, and Timothy J. Sturgeon. 2004. "Globalization, Employment, and Economic Development: A Briefing Paper." Sloan Workshop Series in Industry Studies, Rockport, MA.

Global Insight. 2006. The Role of Metro Areas in the U.S. Economy. Lexington, MA: Global Insight, Inc.

Gordon, David. 1996. Fat and Mean: The Corporate Squeeze of Working Americans and the Myth of Managerial "Downsizing." New York, NY: The Free Press.

Graham, Laurie. 1993. "Inside a Japanese Transplant: A Critical Perspective." Work and Occupations 20:147-73.

Grant, Don Sherman, Jr., and Michael Wallace. 1994. "The Political Economy of Manufacturing Growth and Decline across the American States, 1970-1985." Social Forces 73:33-63.

Harrison, Bennett. 1994. Lean and Mean: The Changing Landscape of Corporate Power in the Age of Flexibility. New York, NY: The Guilford Press.

Harrison, Bennett, and Barry Bluestone. 1982. The Deindustrialization of America: Plant Closings, Community Abandonment, and the Dismantling of Basic Industry. New York, NY: Basic Books.

Hirsch, Barry T. 1980. "The Determinants of Unionization: An Analysis of Interarea Differences." Industrial and Labor Relations Review 33:147-61.

Hirsch, Barry T., and David A. Macpherson 2003. "Union Membership and Coverage Database from the Current Population Survey: Note." Industrial and Labor Relations Review 56:349-54.

Johnston, Paul. 1994. Success While Others Fail: Social Movement Unionism and the Public Workplace. Ithaca, NY: ILR Press

Jones, Ethel B. 1992. "Private Sector Union Decline and Structural Employment Change, 1970-1988." Journal of Labor Research. 13:257-72.

Kalleberg, Arne L., Barbara F. Reskin, and Ken Hudson. 2000. "Bad Jobs in America: Standard in the United States." and Nonstandard Employment Relations and Job Quality American Sociological Review 65:256-78.

Kalleberg, Arne L. 2000. "Non-standard Employment Relations: Part-time, Temporary, and Contingent Work." Annual Review of Sociology 26:341-65. 
Koeller, Timothy. 1994. "Union Activity and the Decline in American Trade Union Membership." Journal of Labor Research 15:19-32.

Lazear, Edward. 1989. "Job Security Provisions and Employment." Quarterly Journal of Economics 105:699-726.

Marshall, F. Ray. 1967. Labor in the South. Cambridge, MA: Harvard University Press.

Marshall, J.N. 1994. "Business Reorganization and the Development of Corporate Services in the Metropolitan Area." The Geographical Journal 160:41-9.

McCall, Leslie. 1998. "Spatial Routes to Gender Wage (In)equality: Regional Restructuring and Wage Differentials by Gender and Education." Economic Geography 74:379-404.

McCune, Joseph T., Richard W. Beatty, and Raymond V. Montagno. 1988. "Downsizing: Practices in Manufacturing Firms." Human Resource Management 27:145-61.

McGovern, Patrick. 2007. "Immigration, Labour Markets, and Employment Relations: Problems and Prospects." British Journal of Industrial Relations 45:217-35.

Milkman, Ruth. 2000. Organizing Immigrants: The Challenges for Unions in Contemporary California. Ithaca, NY: Cornell University Press.

Moore, William J., and Robert J. Newman. 1975. "On the Prospects of Trade Union Growth: A Cross-Section Analysis." The Review of Economics and Statistics 57:435-45.

Polanyi, Karl. 1944. The Great Transformation: The Political and Economic Origins of Our Time. Boston, MA: Beacon Press.

Polivka, Anne E., and Thomas Nardone. 1989. "On the Definition of 'Contingent Work." $\quad$ Monthly Labor Review 112:9-16.

Rosenberg, Sam. 1991. "From Segmentation to Flexibility: A Selective Survey." Review of Radical Political Economics 23:71-79.

Sassen, Saskia. 1999. "Who's City Is It? Globalization and the Formation of New Claims." Pp. 145-162 in Sustainable Cities in the $21^{\text {st }}$ Century, edited by A.F. Foo and Belinda Yuen. Kent Ridge, Singapore: Singapore University Press.

Scruggs, Lyle, and Peter Lange. 2002. "Where Have All the Members Gone? Globalization, Institutions, and Union Density." Journal of Politics 64:126-53.

Smith, Vicki. 1997. "New Forms of Work Organization." Annual Review of Sociology 23:315- 39. 
Sperling, Bert, and Peter Sander. 2004. Cities Ranked and Rated: More than 400 Metropolitan Areas Evaluated in the U.S. and Canada. Hoboken, NJ: Wiley Publishing.

Steger, Manfred. 2003. Globalization: A Very Brief Introduction. Oxford, UK: Oxford University Press.

Troy, Leo, and Neil Sheflin. 1985. Union Sourcebook: Membership, Finances, Structure, Directory. West Orange, NJ: Industrial Relations Data and Information Services.

USITC (United States International Trade Commission). 2002. Shifts in U.S. Merchandise Trade 2001, Appendix C. USITC, Washington, DC.

Vallas, Steven P. 1999. "Rethinking Post-Fordism: The Meaning of Workplace Flexibility." Sociological Theory 17:68-101.

Wallace, Michael, Gordon Gauchat, and Andrew S. Fullerton. 2010. "Globalization, Labor Market Transformation, and Metropolitan Earnings Inequality." Social Science Research 40:15-36.

Wallace, Michael and Andrew S. Fullerton. 2003. "Workers' Earnings in the New Economy." Sociological Focus 36:7-27.

Wallace, Michael, and Joyce Rothschild. 1988. "Plant Closings, Capital Flight, and Worker Dislocation: The Long Shadow of Deindustrialization." Research in Politics and Society 3:1-35.

Wallerstein, Immanuel. 2011. The Modern World-System I: Capitalist Agriculture and the Origins of the European World-Economy in the Sixteenth Century. Berkeley, CA: University of California Press.

Warren, Ronald S., and Robert P. Strauss. 1979. "A Mixed Logit Model of the Relationship between Unionization and Right-to-Work Legislation." The Journal of Political Economy 87:648-55.

Weiler, Paul. 1983. "Promises to Keep: Securing Workers' Rights to Self-Organization under the NLRA." Harvard Law Review 98:351-420.

Western, Bruce. 1995. "A Comparative Study of Working-Class Disorganization: Union Decline in Eighteen Advanced Capitalist Countries." American Sociological Review 60:179-201.

Western, Bruce. 1997. Between Class and Market: Postwar Unionization in the Capitalist Democracies. Princeton, NJ: Princeton University Press.

Whitfield, Dexter. 2001. Public Services or Corporate Welfare? Rethinking the NationState in the Global Economy. London, UK: Pluto Press. 
Figure 1. Total, private, and public sector union density, 1973-2010

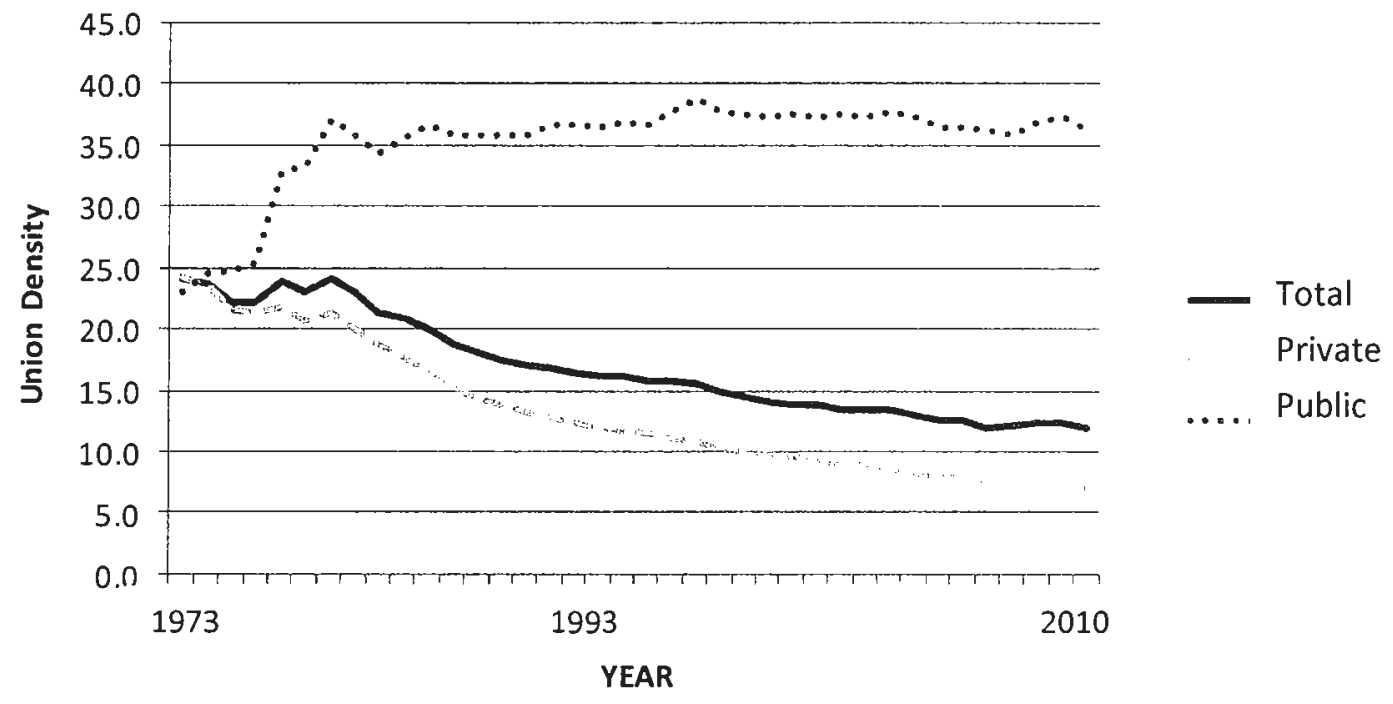


Table 1. Hypothesized effects of the independent variables on total, private and public sector union density

\begin{tabular}{|c|c|c|c|}
\hline Variable & Total union density & Private sector density & Public sector density \\
\hline \multicolumn{4}{|l|}{ Globalization } \\
\hline Global capital & - & - & - \\
\hline Foreign direct investment & - & - & - \\
\hline Exports/GMP & - & - & - \\
\hline Foreign born citizens & + & + & + \\
\hline Foreign born non-citizen & - & - & - \\
\hline \multicolumn{4}{|l|}{ Labor market transformation } \\
\hline Deindustrialization & + & + & + \\
\hline Corporate restructuring & $+/-$ & $+/-$ & $+/-$ \\
\hline Bureaucratic burden & - & - & - \\
\hline Casualization & - & - & - \\
\hline \multicolumn{4}{|l|}{ Labor market structure } \\
\hline Average establishment size & + & + & + \\
\hline Pct. manufacturing employment & + & + & $+/-$ \\
\hline Pct. government employment & + & $+1-$ & + \\
\hline \multicolumn{4}{|l|}{ Business cycle } \\
\hline Unemployment rate & - & - & - \\
\hline Economic growth & + & + & $+/-$ \\
\hline Cost of living & + & + & + \\
\hline \multicolumn{4}{|l|}{ Political climate } \\
\hline Republican state government & - & - & - \\
\hline Democratic state government & $+/-$ & $+/-$ & $+/-$ \\
\hline Right to work law & - & - & - \\
\hline South & - & - & - \\
\hline
\end{tabular}

Note: $N=191$ 
Table 2. Descriptive statistics

\begin{tabular}{|c|c|c|c|c|}
\hline Variable & Mean & Std. Dev. & Min & Max \\
\hline \multicolumn{5}{|l|}{ Union density } \\
\hline Total union density & 12.00 & 7.02 & 0.61 & 32.97 \\
\hline Private sector density & 7.86 & 5.30 & 0.24 & 25.11 \\
\hline Public sector density & 33.60 & 18.55 & 1.32 & 71.17 \\
\hline \multicolumn{5}{|l|}{ Globalization } \\
\hline Global capital & 0.20 & 1.30 & -0.33 & 10.00 \\
\hline Foreign direct investment & 4.68 & 1.43 & 0.77 & 8.98 \\
\hline Exports/GMP & 5.42 & 7.05 & 0.01 & 67.29 \\
\hline Foreign born citizen & 2.91 & 2.70 & 0.42 & 18.54 \\
\hline Foreign born non-citizen & 4.54 & 4.65 & 0.37 & 21.66 \\
\hline \multicolumn{5}{|l|}{ Labor market transformation } \\
\hline Deindustrialization & 175.28 & 51.09 & 43.21 & 374.31 \\
\hline Corporate restructuring & 3.97 & 2.44 & 0.40 & 11.86 \\
\hline Bureaucratic burden & 16.28 & 2.87 & 10.90 & 28.20 \\
\hline Casualization & 16.02 & 2.76 & 11.79 & 34.24 \\
\hline \multicolumn{5}{|l|}{ Labor market structure } \\
\hline Mean establishment size & 16.33 & 2.61 & 10.01 & 21.59 \\
\hline Pct manufacturing employment & 11.26 & 5.49 & 1.60 & 37.58 \\
\hline Pct government employment & 15.21 & 6.11 & 7.35 & 40.91 \\
\hline \multicolumn{5}{|l|}{ Business cycle } \\
\hline Unemployment & 5.80 & 1.90 & 2.84 & 13.09 \\
\hline Economic growth & 6.03 & 1.33 & 2.70 & 10.40 \\
\hline Cost of living & 96.26 & 17.97 & 74.20 & 182.20 \\
\hline \multicolumn{5}{|l|}{ Political climate } \\
\hline Republican state government & 0.26 & 0.44 & 0.00 & 1.00 \\
\hline Democratic state government & 0.19 & 0.40 & 0.00 & 1.00 \\
\hline Right-to-work law & 0.48 & 0.50 & 0.00 & 1.00 \\
\hline South & 0.45 & 0.50 & 0.00 & 1.00 \\
\hline
\end{tabular}

Note: $N=191$ 
Table 3. OLS Determinants of Logit-Transformed Total Union Density in U.S. Metropolitan Statistical Areas, 2000 ( $N=191)$

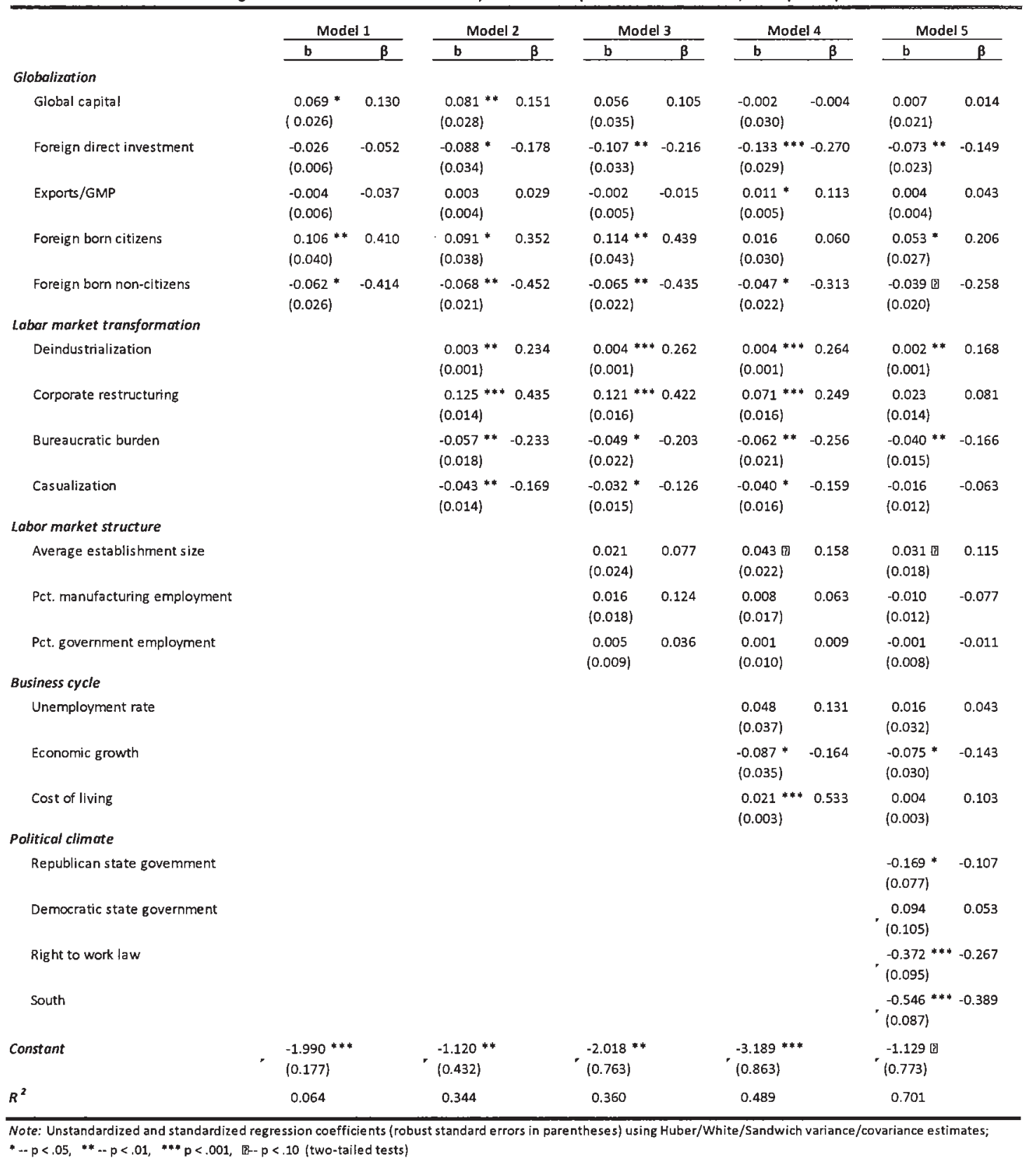


Table 4. OLS Determinants of Logit-Transformed Private Sector Union Density in U.S. Metropolitan Statistical Areas, 2000 (N=191)

\begin{tabular}{|c|c|c|c|c|c|c|c|c|c|c|}
\hline & \multicolumn{2}{|c|}{ Model 1} & \multicolumn{2}{|c|}{ Model 2} & \multicolumn{2}{|c|}{ Model 3} & \multicolumn{2}{|c|}{ Model 4} & \multicolumn{2}{|c|}{ Model 5} \\
\hline & b & $\beta$ & b & $\beta$ & $b$ & $\beta$ & b & $\beta$ & b & $\beta$ \\
\hline \multicolumn{11}{|l|}{ Globalization } \\
\hline Global capital & $\begin{array}{l}0.113^{* * * *} \\
(0.028)\end{array}$ & 0.201 & $\begin{array}{l}0.122 * * * \\
(0.032)\end{array}$ & 0.216 & $\begin{array}{c}0.073^{*} \\
(0.035)\end{array}$ & 0.129 & $\begin{array}{l}0.011 \\
(0.030)\end{array}$ & 0.020 & $\begin{array}{c}0.020 \\
(0.022)\end{array}$ & 0.036 \\
\hline Foreign direct investment & $\begin{array}{l}-0.031 \\
(0.039)\end{array}$ & -0.059 & $\begin{array}{l}-0.094^{*} \\
(0.037)\end{array}$ & -0.182 & $\begin{array}{l}-0.106 * * \\
(0.037)\end{array}$ & -0.204 & $\begin{array}{l}-0.130^{* * *} \\
(0.033)\end{array}$ & -0.250 & $\begin{array}{l}-0.0711^{* *} \\
(0.025)\end{array}$ & -0.137 \\
\hline Exports/GMP & $\begin{array}{c}0.000 \\
(0.007)\end{array}$ & -0.001 & $\begin{array}{c}0.006 \\
(0.006)\end{array}$ & 0.053 & $\begin{array}{l}-0.001 \\
(0.007)\end{array}$ & -0.012 & $\begin{array}{l}0.012 \text { ] } \\
(0.007)\end{array}$ & 0.113 & $\begin{array}{c}0.005 \\
(0.006)\end{array}$ & 0.045 \\
\hline Foreign born citizens & $\begin{array}{c}0.052 \\
(0.041)\end{array}$ & 0.192 & $\begin{array}{c}0.039 \\
(0.042)\end{array}$ & 0.142 & $\begin{array}{c}0.076 \text { 回 } \\
(0.045)\end{array}$ & 0.279 & $\begin{array}{l}-0.025 \\
(0.031)\end{array}$ & -0.090 & $\begin{array}{c}0.015 \\
(0.029)\end{array}$ & 0.053 \\
\hline Foreign born non-citizens & $\begin{array}{l}-0.051 \text { 目 } \\
(0.027)\end{array}$ & -0.321 & $\begin{array}{l}-0.054 * \\
(0.024)\end{array}$ & -0.341 & $\begin{array}{l}-0.052 * \\
(0.025)\end{array}$ & -0.328 & $\begin{array}{l}-0.037 \\
(0.024)\end{array}$ & -0.236 & $\begin{array}{l}-0.029 \\
(0.020)\end{array}$ & -0.185 \\
\hline \multicolumn{11}{|l|}{ Labar market transformotion } \\
\hline Deindustrialization & & & $\begin{array}{c}0.003^{* *} \\
(0.001)\end{array}$ & 0.222 & $\begin{array}{l}0.003^{* *} \\
(0.001)\end{array}$ & 0.236 & $\begin{array}{l}0.003^{* *} \\
(0.001)\end{array}$ & 0.223 & $\begin{array}{l}0.002 \\
(0.001)\end{array}$ & 0.132 \\
\hline Corporate restructuring & & & $\begin{array}{l}0.117^{* * *} \\
(0.015)\end{array}$ & 0.388 & $\begin{array}{l}0.112 * * * \\
(0.016)\end{array}$ & 0.372 & $\begin{array}{l}0.055^{* * *} \\
(0.015)\end{array}$ & 0.184 & $\begin{array}{l}0.007 \\
(0.015)\end{array}$ & 0.023 \\
\hline Bureaucratic burden & & & $\begin{array}{l}-0.056 * * \\
(0.021)\end{array}$ & -0.219 & $\begin{array}{l}-0.050 \text { (1) } \\
(0.028)\end{array}$ & -0.197 & $\begin{array}{l}-0.059 * \\
(0.025)\end{array}$ & -0.228 & $\begin{array}{l}-0.037^{*} \\
(0.017)\end{array}$ & -0.143 \\
\hline Casualization & & & $\begin{array}{l}-0.057^{* * *} \\
(0.016)\end{array}$ & -0.212 & $\begin{array}{l}-0.041 * * \\
(0.015)\end{array}$ & -0.153 & $\begin{array}{l}-0.045^{* *} \\
(0.017)\end{array}$ & -0.169 & $\begin{array}{l}-0.020 \\
(0.015)\end{array}$ & -0.077 \\
\hline \multicolumn{11}{|l|}{ Labar market structure } \\
\hline Average establishment size & & & & & $\begin{array}{c}0.051 \text { [5 } \\
(0.028)\end{array}$ & 0.179 & $\begin{array}{l}0.078 \\
(0.026)\end{array}$ & 0.273 & $\begin{array}{l}0.067^{* *} \\
(0.020)\end{array}$ & 0.234 \\
\hline Pct. manufacturing employment & & & & & $\begin{array}{c}0.012 \\
(0.020)\end{array}$ & 0.092 & $\begin{array}{l}0.004 \\
(0.018)\end{array}$ & 0.028 & $\begin{array}{l}-0.014 \\
(0.013)\end{array}$ & -0.107 \\
\hline Pct. government employment & & & & & $\begin{array}{l}-0.003 \\
(0.010)\end{array}$ & -0.024 & $\begin{array}{l}-0.010 \\
(0.011)\end{array}$ & -0.071 & $\begin{array}{l}-0.012 \\
(0.009)\end{array}$ & -0.090 \\
\hline \multicolumn{11}{|l|}{ Business cycle } \\
\hline Unemployment rate & & & & & & & $\begin{array}{l}0.075^{*} \\
(0.038)\end{array}$ & 0.192 & $\begin{array}{c}0.040 \\
(0.032)\end{array}$ & 0.104 \\
\hline Economic growth & & & & & & & $\begin{array}{l}-0.102 * \\
(0.041)\end{array}$ & -0.184 & $\begin{array}{l}-0.089 * \\
(0.035)\end{array}$ & -0.161 \\
\hline Cost of living & & & & & & & $\begin{array}{l}0.022^{* * *} \\
(0.003)\end{array}$ & 0.533 & $\begin{array}{c}0.005 \\
(0.003)\end{array}$ & 0.118 \\
\hline \multicolumn{11}{|l|}{ Political climote } \\
\hline Republican state govemment & & & & & & & & & $\begin{array}{l}-0.174 * \\
(0.083)\end{array}$ & -0.104 \\
\hline Democratic state government & & & & & & & & & $\begin{array}{c}0.103 \\
(0.102)\end{array}$ & -0.056 \\
\hline Right to work law & & & & & & & & & $\begin{array}{l}-0.393^{* * *} \\
(0.109)\end{array}$ & -0.267 \\
\hline South & & & & & & & & & $\begin{array}{l}-0.536 * * * \\
(0.108)\end{array}$ & -0.362 \\
\hline Constant & $\begin{array}{l}-2.355^{* * *} \\
(0.188)\end{array}$ & & $\begin{array}{l}-1.246 * \\
(0.517)\end{array}$ & & $\begin{array}{l}-2.552 * * \\
(0.805)\end{array}$ & & $\begin{array}{l}-3.984 \\
(0.870)\end{array}$ & & $\begin{array}{l}-2.053^{* *} \\
(0.734)\end{array}$ & \\
\hline$R^{2}$ & 0.063 & & 0.317 & & 0.357 & & 0.493 & & 0.688 & \\
\hline
\end{tabular}


Table 5. OLS Determinants of Logit-Transformed Public Sector Union Density in U.S. Metropolitan Statistical Areas, 2000 (N=191)

\begin{tabular}{|c|c|c|c|c|c|c|c|c|c|c|c|}
\hline & & \multicolumn{2}{|c|}{ Model 1} & \multicolumn{2}{|c|}{ Model 2} & \multicolumn{2}{|c|}{ Model 3} & \multicolumn{2}{|c|}{ Model 4} & \multicolumn{2}{|c|}{ Model 5} \\
\hline & & b & $\beta$ & b & $\beta$ & $b$ & $\beta$ & b & $\beta$ & b & $\beta$ \\
\hline \multicolumn{12}{|l|}{ Globalization } \\
\hline Global capital & & $\begin{array}{l}0.095^{* *} \\
(0.035)\end{array}$ & 0.130 & $\begin{array}{l}0.144 * * * \\
(0.035)\end{array}$ & 0.196 & $\begin{array}{l}0.085 \text { ] } \\
(0.045)\end{array}$ & 0.116 & $\begin{array}{c}0.015 \\
(0.043)\end{array}$ & 0.021 & $\begin{array}{c}0.030 \\
(0.034)\end{array}$ & 0.040 \\
\hline Foreign direct investment & & $\begin{array}{l}-0.021 \\
(0.050)\end{array}$ & -0.031 & $\begin{array}{l}-0.100^{*} \\
(0.041)\end{array}$ & -0.148 & $\begin{array}{l}-0.119 * * \\
(0.041)\end{array}$ & -0.176 & $\begin{array}{l}-0.165 * * * \\
(0.037)\end{array}$ & -0.244 & $\begin{array}{l}-0.083 \\
(0.034)\end{array}$ & -0.123 \\
\hline Exports/GMP & & $\begin{array}{l}-0.010 \\
(0.008)\end{array}$ & -0.072 & $\begin{array}{c}0.001 \\
(0.007)\end{array}$ & 0.006 & $\begin{array}{l}-0.008 \\
(0.007)\end{array}$ & -0.060 & $\begin{array}{c}0.007 \\
(0.007)\end{array}$ & 0.052 & $\begin{array}{l}-0.001 \\
(0.006)\end{array}$ & -0.006 \\
\hline Foreign bom citizens & & $\begin{array}{l}0.195^{* * *} \\
(0.050)\end{array}$ & 0.549 & $\begin{array}{l}0.171 \text { *** } \\
(0.039)\end{array}$ & 0.481 & $\begin{array}{l}0.213^{* * *} \\
(0.053)\end{array}$ & 0.598 & $\begin{array}{c}0.101^{*} \\
(0.046)\end{array}$ & 0.284 & $\begin{array}{l}0.1378^{* * *} \\
(0.040)\end{array}$ & 0.387 \\
\hline Foreign bom non-citizens & & $\begin{array}{l}-0.096^{* *} \\
(0.033)\end{array}$ & -0.465 & $\begin{array}{l}-0.109 * * \\
(0.024)\end{array}$ & -0.526 & $\begin{array}{l}-0.105^{* * *} \\
(0.025)\end{array}$ & -0.507 & $\begin{array}{l}-0.076 * * \\
(0.029)\end{array}$ & -0.370 & $\begin{array}{l}-0.065^{*} \\
(0.027)\end{array}$ & -0.315 \\
\hline \multicolumn{12}{|l|}{ Lobor market transformation } \\
\hline Deindus trialization & & & & $\begin{array}{l}0.004 \text { ** } \\
(0.001)\end{array}$ & 0.216 & $\begin{array}{l}0.004 * * * \\
(0.001)\end{array}$ & 0.237 & $\begin{array}{l}0.005^{* * *} \\
(0.001)\end{array}$ & 0.279 & $\begin{array}{l}0.0035 \\
(0.001)\end{array}$ & 0.186 \\
\hline Corporate restructuring & & & & $\begin{array}{l}0.174^{* * *} \\
(0.019)\end{array}$ & 0.443 & $\begin{array}{l}0.161 \text { *** } \\
(0.021)\end{array}$ & 0.409 & $\begin{array}{l}0.120 * * * \\
(0.020)\end{array}$ & 0.304 & $\begin{array}{l}0.0584 * * \\
(0.019)\end{array}$ & 0.149 \\
\hline Bureaucratic burden & & & & $\begin{array}{l}-0.104 * * * \\
(0.021)\end{array}$ & -0.311 & $\begin{array}{l}-0.074 * * \\
(0.023)\end{array}$ & -0.221 & $\begin{array}{l}-0.105^{* * *} \\
{[0.025)}\end{array}$ & -0.313 & $\begin{array}{l}-0.075^{* * *} \\
(0.022)\end{array}$ & -0.226 \\
\hline Casualization & & & & $\begin{array}{l}-0.034 \text { 방 } \\
(0.019)\end{array}$ & -0.098 & $\begin{array}{l}-0.026 \\
(0.021)\end{array}$ & -0.076 & $\begin{array}{l}-0.052^{* *} \\
(0.020)\end{array}$ & -0.150 & $\begin{array}{l}-0.024 \\
(0.016)\end{array}$ & -0.068 \\
\hline \multicolumn{12}{|l|}{ Labor market structure } \\
\hline Average establishment size & & & & & & $\begin{array}{l}-0.008 \\
(0.026)\end{array}$ & -0.021 & $\begin{array}{c}0.005 \\
(0.026)\end{array}$ & 0.015 & $\begin{array}{l}-0.007 \\
(0.024)\end{array}$ & -0.019 \\
\hline Pct. manufacturing employment & & & & & & $\begin{array}{c}0.037 \text { 回 } \\
(0.020)\end{array}$ & 0.211 & $\begin{array}{c}0.032 \text { [ } \\
(0.019)\end{array}$ & 0.181 & $\begin{array}{c}0.010 \\
(0.015)\end{array}$ & 0.060 \\
\hline Pct. govemment employment & & & & & & $\begin{array}{l}-0.017 \\
(0.011)\end{array}$ & -0.093 & $\begin{array}{l}-0.011 \\
(0.011)\end{array}$ & -0.062 & $\begin{array}{l}-0.014 \\
(0.009)\end{array}$ & -0.079 \\
\hline \multicolumn{12}{|l|}{ Business cycle } \\
\hline Une mployment rate & & & & & & & & $\begin{array}{l}-0.012 \\
(0.049)\end{array}$ & -0.024 & $\begin{array}{l}-0.037 \\
(0.043)\end{array}$ & -0.074 \\
\hline Economic growth & & & & & & & & $\begin{array}{l}-0.040 \\
(0.042)\end{array}$ & -0.056 & $\begin{array}{l}-0.035 \\
(0.040)\end{array}$ & -0.049 \\
\hline Cost of living & & & & & & & & $\begin{array}{l}0.024^{* * *} \\
(0.004)\end{array}$ & 0.451 & $\begin{array}{c}0.005 \\
(0.004)\end{array}$ & 0.093 \\
\hline \multicolumn{12}{|l|}{ Political climote } \\
\hline Republican state govemment & & & & & & & & & & $\begin{array}{l}-0.121 \\
(0.104)\end{array}$ & -0.056 \\
\hline Democratic state government & & & & & & & & & & $\cdot \begin{array}{c}0.061 \\
(0.152)\end{array}$ & 0.025 \\
\hline Right to work law & & & & & & & & & & $\begin{array}{l}-0.413^{* * *} \\
(0.123)\end{array}$ & -0.216 \\
\hline 5outh & & & & & & & & & & $\begin{array}{l}-0.694^{* * *} \\
(0.116)\end{array}$ & -0.361 \\
\hline Constant & $r$ & $\begin{array}{l}-0.813^{* *} \\
(0.242)\end{array}$ & & $\begin{array}{c}0.449 \\
(0.506)\end{array}$ & & $\begin{array}{l}-0.218 \\
(0.929)\end{array}$ & & $\begin{array}{l}-1.178 \\
(1.176)\end{array}$ & & $\begin{array}{c}0.914 \\
(1.107)\end{array}$ & \\
\hline$R^{2}$ & & 0.099 & & 0.397 & & 0.440 & & 0.528 & & 0.690 & \\
\hline
\end{tabular}

Note: Unstandardized and standardized regression coefficients (robust standard errors in parentheses) using Huber/White/Sandwich variance/covariance estimates; *.. p<.05, ** -. p<.01, **** $p<.001,0$ - $-p<.10$ (two-tailed tests) 